\title{
METHODOLOGY AND RESULTS OF THERMAL CALCULATION OF ONE-THROUGH STEAM GENERATORS FOR NPP OF SMALL POWER
}

\author{
V.P. Kravchenko, Xiaolong Zhou \\ Odessa National Polytechnic University, Odessa, Ukraine \\ E-mail: kravchenko@opu.ua; tel.+38-050-390-17-92
}

\begin{abstract}
Due to the invaluable interest in small-scale nuclear power plants around the world, it has been proposed to pay sufficient attention to the design of appropriate equipment, which can make Ukraine with its great potential as a producer a supplier of such nuclear power plants. The work considers the method of thermal calculation of a oncethrough steam generator with a coil heating surface and superheating of steam. As a result of analysis and comparison of the results, formulas were selected for calculating six different conditions of heat transfer: lumbar flow around the coil package with coolant and five heat transfer sections during the movement of the working fluid in the tube. The results of calculating the heat transfer surface for a steam generator with a capacity of $45 \mathrm{MW}$ are presented. The obtained results correlate well with the calculation data by the ASPEN-TECH computer code.
\end{abstract}

\section{INTRODUCTION}

The relevance of the technology of small modular reactors (SMR) is already evidenced by the fact that only 2020 holds several international conferences of world level [1,2]. This indicates a great interest in SMR technology and its broad prospects. The most ready-touse for today is NuScale technology, which is described in the IAEA report [3].

Extensive experience in the design, manufacture and operation of low-power nuclear power plants (NPP) accumulated in the icebreaking and submarine fleet. Reactor installation (RI) KLT-40 (ship icebreaking type) with a capacity of $150 \mathrm{MW}$ (therm.) installed on modern lighter carriers "Sevmorput", icebreakers "Taimyr", and "Vaigach", as well as on the floating NPP "Akademik Lomonosov" [4].

Today's prospects of nuclear energy in Ukraine are associated with RI SMR-160, which is being designed by the American company Holtec International [5]. Ukraine with its powerful production potential of power engineering could take its rightful place in the world in the production of appropriate equipment for SMR, necessary for use both in our country and for export abroad.

One of the main elements of NPP equipment is a steam generator, the calculation of which is the object of consideration in this article. It should be noted that in the mentioned projects, options with natural and forced circulation are considered. Regardless of the possible design options, a mandatory section in the design of the steam generator is its thermal calculation.

The aim of the article is to refine the methods of thermal calculation and calculation of a $45 \mathrm{MW}$ steam generator.

For further consideration, a NPP with a thermal capacity of $180 \mathrm{MW}$ was adopted, the prototype of which is the KLT-40S NPP [6].

\section{DESCRIPTION OF THE DESIGN OF THE STEAM GENERATOR}

One-through type steam generator: feed water enters in the heat exchange tubes (HET) (coils), on the output of which is superheated steam. The main characteristics of the steam generator:
- fluids movement - counter flow;

- the coolant of the 1st circuit (water under pressure) moves from top to bottom in the annulus. That is, there is a lumbar flow around the tubes at an angle;

- coolant of the 2 nd circuit (feed water - steam water mixture - superheated steam) moves inside the pipes from the bottom up along a curved path.

Heat transfer surface consists of cylindrical rows of coils. Each row (layer) has a different number of tubes. The number of tubes in the layer is determined from the condition of equal length of tubes in different rows. The main parameters of the coolants are given in the table.

The main parameters of the coolants in the steam generator

\begin{tabular}{|lc|l|}
\hline \multicolumn{2}{|l|}{ Thermal power, MW } & 45 \\
\hline \multicolumn{2}{|l|}{ Mass flow of steam, $\mathrm{t} / \mathrm{h}$} & 62.1 \\
\hline Steam parameters: & $\mathrm{P}, \mathrm{MW}$ & 3 \\
& $\mathrm{t},{ }^{\circ} \mathrm{C}$ & 275 \\
\hline Feed water temperature, & ${ }^{\circ} \mathrm{C}$ & 65 \\
\hline Coolant temperature, ${ }^{\circ} \mathrm{C}: \quad \begin{array}{c}\text { Entrance } \\
\end{array} \quad$ Exit & 297.8 \\
& 270 \\
\hline Coolant pressure at the inlet, $\quad \mathrm{MPa}$ & 15 \\
\hline
\end{tabular}

Heat transfer tubes made of titanium alloy ПТ-7M.

\section{METHODOLOGY OF THERMAL CALCULATION OF ONE-THROUGH STEAM GENERATOR [7-10]}

Constructive calculation with given (accepted) characteristics determines the amount of HET, external dimensions. The required characteristics are usually: the diameter and steps between the HET, as well as the speed at the entrance to the tubes. When using a coil surface of cylindrical layers this is not enough. The number of layers is determined by the velocity of the coolant in the annulus or, conversely, given the number of rows of cylindrical coils, it is possible to obtain the velocity of the coolant in the annulus. Thus, the coil heating area, for definiteness, requires one more independent parameter than conventional heat exchangers [6]. 
The heat exchange area is calculated for five sections in which different heat transfer conditions for the working fluid:

Economizer (ECS): $\quad 1$ - Convective heat transfer; 2 - Surface boiling.

Evaporator (EVS): $\quad 3$ - Developed boiling EVS; 4 - poor heat transfer EVS.

Superheater (SUS): 5 -Overheating steam.

The first stage of the thermal calculation is the construction of $\mathrm{t}, \mathrm{Q}-\mathrm{SG}$ diagrams, determining the power, transmitted on the ECS, EVS, and SUS (Figure).

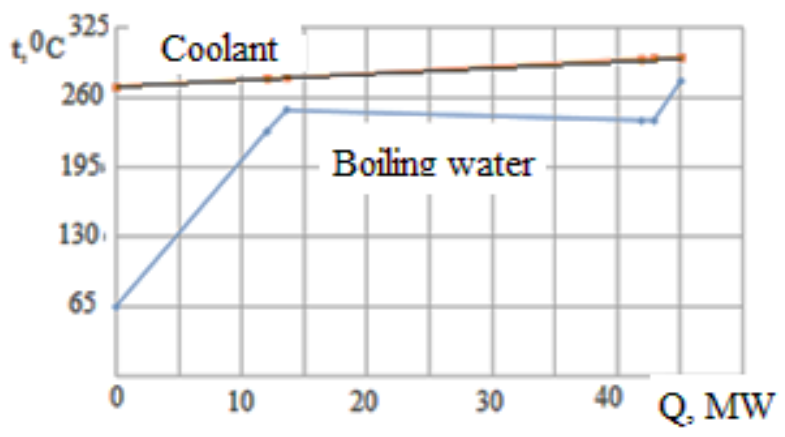

t, $Q$ - steam generator diagram

The boundary between the first and second zones of the economizer section is determined from the condition: the temperature of the inner surface of the wall is equal to the boiling point $t_{w}^{i n}=t_{s}$. To determine the fraction of heat transferred to ECS1, it is necessary to calculate the temperatures on the inner surface of the wall at the inlet and outlet of the economizer section $t_{w 1}^{i n}$ and $t_{w 2}^{i n}$. To do this, at these points it is necessary to calculate the heat transfer coefficient from the coolant to the wall, the heat transfer coefficient from the wall to the working fluid, the heat transfer coefficient at an average wall temperature, the heat transfer coefficient, and heat flux. Hence, the thermal power of the first economizing section is defined as:

$$
\mathrm{Q}_{E C S 1}=\mathrm{Q}_{E C S} \cdot \frac{t_{s}-t_{w 1}^{i n}}{t_{w 2}^{i n}-t_{w 1}^{i n}}
$$

where $\mathrm{Q}_{E C S}$ - thermal power economizer section.

The heat transfer coefficient (HTC) from the wall to the feed water which moves in the pipes, is determined by the formula [8]:

$$
\alpha_{\text {fw.ECS1 }}=0.023 \cdot\left(\lambda / d_{\text {in }}\right) \cdot \operatorname{Re}^{0.8} \cdot \operatorname{Pr}^{0.4}\left(\mu_{\mathrm{f}} / \mu_{\mathrm{w}}\right)^{0.11} .
$$

where $\lambda$ - thermal conductivity of water, $\mathrm{W} /(\mathrm{m} \cdot \mathrm{K})$; $\mathrm{d}_{\mathrm{in}}$ - inner diameter HET, $\mathrm{m}$; Re, Pr - Reynolds and Prandtl numbers; $\mu_{\mathrm{f}}, \mu_{\mathrm{w}}-$ dynamic viscosity coefficients of water at an average temperature at ECS1 and at a temperature of the inner wall surface.

The movement in the coil increases HTC, which is taken into account by the coefficient:

$$
\mathrm{K}=1+3.5 \mathrm{~d}_{\text {in }} / \mathrm{D}_{\text {coil }} \text {, }
$$

where $\mathrm{D}_{\text {coil }}-$ coil diameter.

As you can see, to determine HTC, you should first take the temperature of the inner surface of the wall. The heat transfer from the coolant to the wall during the transverse flow around the coils for all sections is determined identically [9]:

$$
\alpha_{\mathrm{C}}=0.02 \lambda / \mathrm{d}_{\text {out }} \cdot \operatorname{Re}^{0.84} \cdot \operatorname{Pr}^{0.36} .
$$

where $\mathrm{d}_{\text {out }}$ - outside diameter of HET.

Attack angle $\varphi$, which differs from $90^{\circ}$ is taken into account by multiplying by a coefficient:

$$
K=1-0.54 \cos ^{2} \varphi \text {. }
$$

The coolant velocity in the annulus is defined as the highest at the smallest intersection.

Next, you should take the average wall temperature, determine from it the thermal conductivity of the wall (for $\Pi \mathrm{T}-7 \mathrm{M}), \mathrm{W} /(\mathrm{m} \cdot \mathrm{K})$ :

$$
\lambda_{\mathrm{w}}=0.002 \cdot \mathrm{t}_{\mathrm{w}}+14.873,
$$

determine heat transfer coefficient:

$$
k_{E C S}=\left(\frac{1}{\alpha_{\mathrm{fw} . \mathrm{ECS}}}+\frac{\delta_{w}}{\lambda_{w}}+\frac{1}{\alpha_{\mathrm{c} . \mathrm{ECS}}}+R_{f}\right)^{-1},
$$

$R_{\mathrm{f}}$ is fouling resistance inside the tube, $R_{\mathrm{f}}=8.8 \cdot 10^{-6}\left(\mathrm{~m}^{2} \cdot \mathrm{K}\right) / \mathrm{W}$.

As a result determine the heat flux, $\mathrm{W} /\left(\mathrm{m}^{2} \cdot \mathrm{K}\right)$ :

$$
\mathrm{q}=k \cdot \Delta t_{\text {log }}^{E C S}
$$

where $\Delta t_{\text {log }}^{E C S}$ - logarithmic temperature difference.

Using the known heat flux and HTC from the wall to the working fluid and from the coolant to the wall, the wall temperatures on the internal and external surfaces are specified:

$$
\begin{aligned}
& t_{w}^{i n}=t_{f w}^{a v r}+\frac{\mathrm{q}}{\alpha_{\mathrm{fw} . \mathrm{ECS}}} ; \\
& t_{w}^{\text {out }}=t_{c}^{a v r}-\frac{\mathrm{q}}{\alpha_{\text {c.ECS }}} .
\end{aligned}
$$

With a large difference between the previously accepted and received values, the wall temperatures are restarted and the calculation is repeated.

After calculating the thermal power of the first and second economizer sections, the first economizer section ECS1 is calculated similarly to the previous calculation. Heat transfer area (HTA):

$$
\mathrm{S}_{\mathrm{ECS} 1}=\mathrm{Q}_{\mathrm{ECS} 1} /\left(\kappa_{\mathrm{ECS} 1} \cdot \Delta t_{\mathrm{ECS} 1}\right) \text {. }
$$

When determining the height of the HTA, it must be taken into account that the thermal conductivity coefficient is determined by the average diameter of the tube.

Water underheated to saturation temperature boils on ED2 [8]:

$$
\alpha_{\mathrm{fw} . \mathrm{ECS}}=\alpha_{0} \cdot\left\{1+\left[\alpha_{0} \cdot\left(\frac{1}{\alpha_{\mathrm{K}}}-\frac{t_{s}-t_{f}}{q}\right)\right]^{-3 / 2}\right\}^{2 / 3},
$$

where

$$
\alpha_{0}=10.45 \cdot \frac{\mathrm{q}^{0,7}}{3.3-0.0113 *\left(t_{s}-100\right)}
$$

$\mathrm{q}-$ specific heat flux, $\mathrm{W} / \mathrm{m}^{2} ; \alpha_{\mathrm{K}}-$ is determined by expression $(1) ;\left(t_{s}-t_{f}\right)-$ underheating of liquid to saturation temperature.

The calculation algorithm in the second economizer section ECS2 is similar to the previous one except that it is necessary to accept the heat flux q. To determine the thermal conductivity of the wall in this area, one also has to take the average wall temperature. After that, HTC from the coolant, HTC $k$, heat flux and wall temperature on both surfaces of the HET are calculated. The calculation is considered complete if the accepted and 
received values of the heat flux and wall temperatures are close enough.

The boundary between the third and fourth sections is determined by the formula for calculating $x_{\mathrm{b}}$ (vapor content) in the evaporation region. At the point of $x_{\mathrm{b}}$ the zone of developed boiling passes into the zone of impaired heat transfer [8]:

$$
\begin{gathered}
x_{b}=\left(0.39+0.16 \cdot \mathrm{P}-0.0212 \cdot \mathrm{P}^{2}+0.00072 \cdot \mathrm{P}^{3}\right) \cdot \\
\sqrt{\frac{1000}{\rho^{\prime} \omega_{0}}} \cdot\left(\frac{0,008}{d}\right)^{0.25}
\end{gathered}
$$

where $\mathrm{P}$ - pressure, bap; $\rho^{\prime}$ - saturated water density, $\mathrm{kg} / \mathrm{m}^{3} ; \omega_{0}-$ the speed of the water in the pipe, provided that it is saturated, $\mathrm{m} / \mathrm{s} ; d$ - tube inner diameter, $\mathrm{m}$.

On EVS1 is developed boiling in channels [8]:

$$
\begin{aligned}
& x=0 \text { : } \\
& \alpha_{\mathrm{EVS}}^{\prime}=\alpha_{0} \cdot\left\{1+\left[\left(\frac{\alpha_{0}}{\alpha_{\mathrm{K}}}\right)\right]^{-\frac{3}{2}}\right\}^{\frac{2}{3}}, \\
& \alpha_{k}=0.023 \cdot \frac{\lambda}{\mathrm{dH}} \cdot \operatorname{Re}^{0.8} \cdot \operatorname{Pr}^{0.4} \cdot\left(\frac{\mu^{\prime}}{\mu^{\prime \prime}}\right)^{0.11}, \\
& x=x_{b} \text { ： } \\
& \alpha_{1}=\sqrt{\alpha_{\mathrm{K}}^{2}+\left(0.7 \alpha_{0}\right)^{2}}, \\
& \alpha_{E V S 1}=\left(\alpha_{\mathrm{EVS}}^{\prime}+\alpha_{E V S}^{\prime \prime}\right) / 2 \text {, } \\
& N u=\frac{\left(\frac{\xi}{8}\right) \cdot \operatorname{Re} \cdot \operatorname{Pr} \cdot C_{t}}{k+4.5 \sqrt{\xi} \cdot\left(\operatorname{Pr}^{2 \mid 3}-1\right)} ; \\
& k=1+900 / \operatorname{Re} \text {; } \\
& \xi=(1.82 \cdot \lg R e-1.62)^{-2} ; \\
& C_{t}=\left(\mu_{\mathrm{f}} / \mu_{\mathrm{w}}\right)^{0.11},
\end{aligned}
$$$$
\alpha_{E V S}^{\prime \prime}=\alpha_{1} \cdot \sqrt{1+7 \cdot 10^{-9}\left(\frac{\rho \prime \omega_{\mathrm{cm}} r}{q}\right)^{3 / 2} \cdot\left(0.7 \cdot \alpha_{0} / \alpha_{1}\right)^{2}},
$$

where $\alpha_{\mathrm{K}}-$ HTC during a single-phase fluid flow, de-

$\alpha_{0}$ is determined by (12),

$$
\omega_{\mathrm{M}}=\omega_{0}\left[1+\mathrm{x}\left(\frac{\rho^{\prime}}{\rho^{\prime \prime}}-1\right)\right]
$$

$\mathrm{X}$ - average steam content in the area.

The HTC in this area was determined as the arithmetic mean at the input and output of the section.

On the EVS2 is reduced boiling zone. It was calculated in accordance with [9]:

$$
\begin{aligned}
& \alpha_{E V S ~}=\sqrt{\left[\alpha^{\prime \prime} \cdot \frac{x-x_{b}}{1-x_{b}}\right]^{2}+\left[\alpha^{\prime} \cdot \frac{1-x}{1-x_{b}}\right]^{2}+\left[0,7 \cdot \alpha_{0} \cdot \frac{1-x}{1-x_{b}}\right]^{2}} \\
& N u^{\prime}=0.023 \cdot \operatorname{Pr}^{\prime 0.4} \cdot \operatorname{Re}^{\prime 0.8} \cdot\left(\frac{P r_{f}}{P r_{w}}\right)^{0.11} \cdot k \\
& N u^{\prime \prime}=0.023 \cdot \operatorname{Pr}^{\prime \prime} 0.4 \cdot \operatorname{Re}^{\prime \prime} 0.8 \cdot\left(\frac{T_{w}}{T_{f}}\right)^{(-0.55)} \cdot k \\
& k=1+6.6 \cdot\left(1-\frac{d_{\text {in }}}{D_{\text {coil }}}\right)\left(\frac{d_{\text {in }}}{D_{\text {coil }}}\right)^{1.15} ; \\
& \alpha_{0}=4.34 \cdot q^{0.7} \cdot\left(\mathrm{P}^{0.14}+1.37 \cdot 10^{-2} \cdot \mathrm{P}^{2}\right) .
\end{aligned}
$$

Superheater section (SUS). During the flow of gases in curved channels, it is proposed [8]:

$$
\begin{aligned}
\mathrm{Nu}_{\text {SUS }}= & 0.038 \cdot \operatorname{Re}^{0.8} \cdot \frac{P r}{\operatorname{Pr}^{\frac{2}{3}}-0.074}\left(\frac{d_{\text {in }}}{D_{\text {coil }}}\right)^{0.1} \times \\
& \left\{1+\frac{0.098}{\left[\operatorname{Re}\left(\frac{\mathrm{d}_{\text {in }}}{D_{\text {coil }}}\right)^{2}\right]^{0.2}}\right\} .
\end{aligned}
$$

\section{CALCULATION RESUltS}

According to the presented methodology, a directlow steam generator was calculated with the initial data given earlier (Table).

From the above data it is seen that when the coolant moves with a decrease in its temperature, the HTC gradually decreases. The HTC of the working fluid is significantly less than the HTC from the coolant in all areas of heat transfer.

The main results of the calculation of a once-through steam generator with a coil heat area surface

\begin{tabular}{|c|c|c|l|l|l|}
\hline Indicators & ECS1 & ECS2 & EVS1 & EVS2 & SUS \\
\hline$Q, \mathrm{~kW}$ & 11272 & 2328 & 18274 & 5641 & 2129 \\
\hline$q, \mathrm{~kW} / \mathrm{m}^{2}$ & 31.2 & 178.3 & 180.3 & 102.3 & 69.74 \\
\hline $\begin{array}{c}\alpha_{\mathrm{c}}, \\
\mathrm{kW} /\left(\mathrm{m}^{2} \cdot \mathrm{K}\right)\end{array}$ & 40.84 & 41.09 & 41.59 & 42.15 & 42.31 \\
\hline $\begin{array}{c}\alpha_{\mathrm{wf}}, \\
\mathrm{kW} /\left(\mathrm{m}^{2} \cdot \mathrm{K}\right)\end{array}$ & 6.34 & 39.44 & 92.99 & 7.7 & 3.045 \\
\hline$t_{w}^{\text {avr }},{ }^{\circ} \mathrm{C}$ & 228.6 & 255.8 & 264.6 & 272.5 & 287.5 \\
\hline $\begin{array}{c}\text { Flow rate of } \\
\text { coolant, } \mathrm{m} / \mathrm{s}\end{array}$ & 4.02 & 4.06 & 4.207 & 4.23 & 4.25 \\
\hline $\begin{array}{c}\text { Flow rate of } \\
\text { working } \\
\text { fluid, } \mathrm{m} / \mathrm{s}\end{array}$ & 0.604 & 0.68 & 26.98 & 33.83 & 38.5 \\
\hline$k, \mathrm{~kW} /\left(\mathrm{m}^{2} \cdot \mathrm{K}\right)$ & 2.676 & 4.158 & 4.249 & 1.838 & 1.846 \\
\hline$\Delta t_{\text {log }},{ }^{\circ} \mathrm{C}$ & 116.6 & 42.9 & 40.7 & 55.5 & 37.8 \\
\hline${\mathrm{HTA}, \mathrm{m}^{2}}^{2}$ & 36.12 & 13.05 & 186.7 & 55.3 & 30.5 \\
\hline Height, $\mathrm{m}$ & 0.349 & 0.126 & 1.8 & 0.534 & 0.29 \\
\hline
\end{tabular}

As a result, the wall temperature is close to the temperature of the coolant. The thermal resistance of the wall is essential. At the economizer site, it is even more than the thermal resistance of heat transfer of the working fluid. This indicates the feasibility of searching for material for heat transfer tubes with a high coefficient of thermal conductivity and better strength characteristics.

The overall dimensions of the steam generator resulting from the calculation coincide with the calculation data using the ASPEN-TECH computer code.

\section{CONCLUSIONS}

1. An algorithm and a program for calculating a one through steam generator for low power NPP with a coil heating area have been developed. This program can be used to optimize parameters when designing steam generators of a similar design.

2. The calculation showed good coincidence between the obtained values of the overall dimensions of the steam generator and the calculation data of the ASPEN-TECH computer code. 


\section{REFERENCES}

1. Annual International SMR and Advanced Reactor Summit

https://www.nuclearenergyinsider.com/internationalsmr-advanced-reactor/brochure-thank-you.php (Date of the application 21.02.2020).

2. International Conference on Generation IV and Small Reactor http://g4sr.org/ (Date of the application 21.02.2020).

3. Advances in Small Modular Reactor Technology Developments. https://aris.iaea.org/Publications/SMRBook_2018.pdf (Date of the application 21.02.2020).

4. Реакторная установка КЛТ-40 https://ru.wikipedia.org/wiki/\%D0\%9A\%D0\%9B\%D0 $\% \mathrm{~A} 2-40$ (Date of the application 21.02.2020).

5. Уникальные возможности Украины для внедрения технологий SMR-160 http://www.energoatom.com.ua/files/file/smr_160_for_ naek_industry_forum_rus.pdf (Date of the application 21.02.2020)
6. V.P. Kravchenko, R.M. Sereda, Zhou Xiaolong, Yu.I. Visotskii, A.H. Rybakov. Choice of basic construction parameters of steam generators for NPP of low power // Problems of Atomic Science and Technology. 2019, N 5(125), p. 62-68.

7. Д.Ф. Романов, М.А. Лебедев, С.С. Саваренский, Н.П. Шаманов. Судовые ядерные паропроизводящие установки. Л.: «Судостроение», 1967, $404 \mathrm{c}$.

8. П.Л. Кириллов, Ю.С. Юрьев, В.П. Бобков. Справочник по теплогидравлическим расчетам (ядерные реакторы, теплообменники, парогенераторы). М.: «Энергоатомиздат», 1990, 360 с.

9. РД 24.035.05-89. Методические указания. Тепловой и гидравлический расчет теплообменного оборудования АЭС.

http://docs.cntd.ru/document/1200085786 (Date of the application 21.02.2020).

10. М.А. Михеев, И.М. Михеева. Краткий курс теплопередачи. М.-Л.: «Госэнергоиздат», 1960, $208 \mathrm{c}$.

Article received 02.03.2020

\section{МЕТОДИКА И РЕЗУЛЬТАТЫ ТЕПЛОВОГО РАСЧЕТА ПРЯМОТОЧНОГО ПАРОГЕНЕРАТОРА ДЛЯ АЭС МАЛОЙ МОЩНОСТИ}

\section{В.П. Кравченко, Сяолун Чжоу}

В связи с большим интересом во всем мире к АЭС малой мощности предложено уделять достаточное внимание проектированию соответствующего оборудования, что может сделать Украину с ее мощным потенциалом производителя поставщиком таких АЭС. В работе рассмотрена методика теплового расчета прямоточного парогенератора со змеевиковой поверхностью нагрева и перегревом пара. В результате анализа и сопоставления результатов были выбраны формулы для расчета шести различных условий теплообмена: поперечного обтекания пакета змеевиков теплоносителем и пяти участков теплообмена при движении рабочего тела в трубке. Приведены результаты расчета поверхности теплообмена для парогенератора мощностью 45 МВт. Полученные результаты хорошо коррелируют с данными расчета компьютерным кодом ASPEN-TECH.

\section{МЕТОДИКА ТА РЕЗУЛЬТАТИ ТЕПЛОВОГО РОЗРАХУНКУ ПРЯМОТОЧНОГО ПАРОГЕНЕРАТОРА ДЛЯ АЕС МАЛОЇ ПОТУЖНОСТІ}

\section{В.П. Кравченко, Сяолун Чжсоу}

У зв'язку з великим інтересом у всьому світі до АЕС малої потужності запропоновано приділяти достатню увагу проектуванню відповідного устаткування, що може зробити Україну з ії великим потенціалом виробника постачальником таких АЕС. В роботі розглянуто методику теплового розрахунку прямоточного парогенератора зі змієвиковою поверхнею нагріву та перегрівом пара. В результаті аналізу та співставлення результатів було вибрано формули для розрахунку шести різних умов теплообміну: поперекового обтікання пакету змієвиків теплоносієм та п’яти ділянок теплообміну при русі робочого тіла в трубці. Наведено результати розрахунку поверхні теплообміну для парогенератору потужністю 45 МВт. Отримані результати добре корелюються з даними розрахунку комп'ютерним кодом ASPEN-TECH. 